\title{
Energy Use, Energy Savings and Environmental Analysis of Industrial Boilers and Compressors
}

\author{
R. Saidur ${ }^{a, c}$, M. Hasanuzzaman ${ }^{a, c, *}$, N.A. Rahim $^{\text {b,c }}$ \\ ${ }^{a}$ Department of Mechanical Engineering, University of Malaya, 50603 Kuala Lumpur, Malaysia \\ ${ }^{b}$ Department of Electrical Engineering, University of Malaya, 50603 Kuala Lumpur, Malaysia \\ ${ }^{c}$ Centre of Research UMPEDAC, Faculty of Engineering, University of Malaya, 50603 Kuala Lumpur, Malaysia
}

\begin{abstract}
In this paper energy use, energy and bill savings, emission reduction and pay period using high efficient motor, variable speed drive by modulating speed of boiler and compressor has been estimated using energy audit data. It has been found that $68,923 \mathrm{MWh}, 132,922 \mathrm{MWh}, 78,769 \mathrm{MWh}$ and $49,230 \mathrm{MWh}$ of energy can be saved for $40 \%, 60 \%, 80 \%$ and $100 \%$ motor loadings, respectively for $20 \%$ speed reduction in the boiler system. Corresponding bill savings for the aforementioned energy savings have been found to be US\$ 4,411,052, US\$ $8,507,028$, US $\$ 5,041,202$, and US\$ $43,150,751$ for $40 \%, 60 \%, 80 \%$ and $100 \%$ motor loadings, respectively for $20 \%$ speed reduction in the boiler system. Energy savings and bill savings resulting from the use of high-efficiency motor in air compressor are $6703 \mathrm{MWh}, 8251$ MWh, and $10571 \mathrm{MWh}$, total energy, can be saved for $50 \%, 75 \%$, and $100 \%$, motor loadings, respectively. Similarly, bill savings for the preceding amounts of energy savings are US\$ 428,984, US\$ 528,042 and US\$ 676,538, respectively. It is also clear that the use of high efficiency motor and VSDs leads to substantial energy savings and an enormous reduction in emissions.
\end{abstract}

Keywords: Energy, Energy savings, Environment, Boiler, Compressor.

\section{Introduction}

Energy efficiency improvement is one of the most important functions to reduce energy cost as well as production cost in the industries. Energy efficiency improvement is the main objective of many national energy policies. Monitoring of the energy consumption and developments in energy efficiency is necessary in order to check and apply desired policies. Energy is the most important sector for automation and modernization. Automation and modernization is increasing rapidly day by day in the industrial sectors. Steam and compress air systems are a part of almost every major industrial process today. All of the major industrial energy users devote significant proportions of their fossil fuel consumption to steam production: food processing (57\%), pulp and paper (81\%), chemicals (42\%), petroleum refining $(23 \%)$, and primary metals $(10 \%)$. Since industrial systems are very diverse, but often have major steam systems in common, it makes a useful target for energy efficiency measures [1]. Nearly $45 \%$ of global electricity generation is derived from coal while natural gas and nuclear energy makes up about $20 \%$ and $15 \%$ respectively of the world's generated electricity [2]. Most heating systems, although not all, employ boilers to produce hot water or steam. Boiler efficiency therefore has an important influence on heating-related energy savings. The energy savings that can be achieved by improving overall boiler efficiency can be substantial. Essentially a boiler is a device in which a fossil fuel is burnt and the heat produced is transferred to water. Heat can be lost from boilers by a variety of methods, including flue gas losses, radiation losses and, in the case of steam boilers, blow-down losses [3]. To optimize the operation of a boiler plant, it is necessary to identify where energy wastage is likely to occur. A significant amount of energy is lost through flue gases as all the heat produced by the burning fuel cannot be transferred to water or steam in the boiler. The efficiency of boiler is a measure of the ability of it to generate the steam demand from a given fuel supply. Boiler efficiency is very dependent on the excess air rate. Excess air should be kept at the lowest practical level to reduce the quantity of unneeded air that is heated and exhausted at the stack temperature [4]. Most of the heat losses from the boiler appear as heat in the flue gas, the recovery of this heat can result in substantial energy savings $[5,6]$.This indicates that there is huge savings potentials of a boiler energy savings by minimizing its losses. By introducing variable speed to the driven load, it is possible to optimize the efficiency of the entire system, and it is in this area that the greatest efficiency gains are possible $[7,8]$. Use of compressed air in industry and in service sectors is common as its production and handling are safe and easy. In most industrial facilities, compressed air is necessary to manufacturing. Compressed-air generation is energy intensive, and for most industrial operations, energy cost fraction of compressed air is significant compared with overall energy costs. There is a vacuum of reliable information

${ }^{*}$ Corresponding author. Tel.: +60379677611

Fax: +60379675317; E-mail: hasan@um.edu.my

(C) 2010 International Association for Sharing Knowledge and Sustainability

DOI: 10.5383 /ijtee.01.01.005 
on the energy efficiency of a typical compressed air system $[9,10]$. As a general rule, compressed air should be used only if safety enhancements, significant productivity gains, or labour reduction, will result as it is very expensive. Annual operating costs of air compressors, dryers, and supporting equipment, can account from $70 \%$ to $90 \%$ [11] of the total electric bill. Energy losses in a large number of industries exist, and there is evident potential for energy efficiency improvements [12]. Among the various sectors contributing to greenhouse gas emissions, the contribution of the industrial sector was significant. Thus, lowering GHG emissions from the industrial sector offers the means of reducing overall GHG emissions. Energy conservation means less reliance on energy imports and, thus, less GHG emissions. Previous studies have reported that implementing a few select options at little or no cost in the industrial sector could reduce GHG emissions by $10-30 \%$ of GHG emissions [13].

The aim of the paper is to the details estimation of boiler and compressor motor energy use, energy savings and environmental analysis using VSD and high efficiency motor. It is expected that the estimation will be very useful for industry, policy makers, energy users and researchers.

\section{Excess Air Control}

A boiler should always be supplied with more combustion air than theoretically required in order to ensure complete combustion and safe operation. At the same time, boiler efficiency is very dependent on the excess air rate. Therefore, the excess air should be optimized to increase the system efficiency. Qureshi and Tassou [14] reviewed the VSD in refrigeration application to reduce energy uses that is shown in Figure 1.

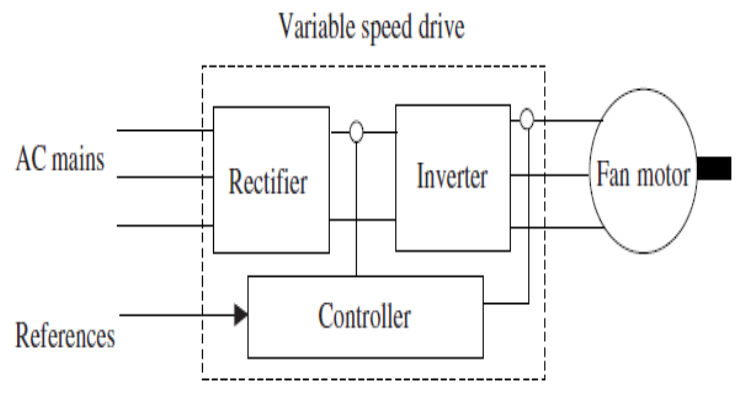

Fig. 1 Block diagram of the variable speed drive system [4]

Combustion efficiency can be improved at low fire if the fan speed is reduced. The fan motor speed control is an easy to add option on some electronic controls. The benefit of variable speed drive by using an inverter to slow down an AC electric motor causes electrical energy saving. Electric motors are over $90 \%$ efficient when running at their rated loads. Conventional electric motors typically use $60 \%$ to $80 \%$ of their rated input energy, even when running at less than $50 \%$ load [15].

\section{Methodology}

\subsection{Data Collection for Boiler}

Malaysian Energy Centre (MEC) conducted energy audit for 48 industrial facilities for about 2 years starting from 2002 2004 [16]. It was a detailed energy audit. Summary of type and number of industry visited is shown in Table 1 . Number of fan motor and their corresponding power, motor loadings, and usage hours are presented in Tables 2-3. These are the data needed for boiler fan motor energy analysis.

Table 1 Types and number of audited industry

\begin{tabular}{cc}
\hline Industry & No \\
\hline Food & 10 \\
Wood & 7 \\
Ceramic & 6 \\
Cement & 3 \\
Glass & 3 \\
Rubber & 9 \\
Pulp and paper & 6 \\
Iron and steel & 4 \\
Total & 48 \\
\hline
\end{tabular}

Table 2 Boiler operating time with its loading

\begin{tabular}{cc}
\hline Boiler loading & Operating hours/yr \\
\hline $100 \%$ & 720 \\
$80 \%$ & 1440 \\
$60 \%$ & 3240 \\
$40 \%$ & 2520 \\
\hline
\end{tabular}

Table 3 Input data for motor energy analysis

\begin{tabular}{cc}
\hline Motor power $(\mathrm{kW})$ & Quantity \\
\hline 11 & 50 \\
15 & 66 \\
19 & 21 \\
22 & 15 \\
30 & 17 \\
37 & 9 \\
45 & 5 \\
56 & 3 \\
\hline
\end{tabular}

\subsection{Data collection for air compressor}

Data were collected in a walkthrough energy audit. The reference [17] contains details of the energy audit. The most important data collected during the walkthrough audit were the power ratings, the operation times of energy-using equipment/machinery, fossil fuel and other sources used for energy, production figures, tariff usage behavior (peak and offpeak), and power factor. Table 4 shows the number of factories audited in a sector. Table 5 presents the total energy used by compressed-air systems that is about 239,450 MWh energy. 


\subsection{Energy Use of Compressed-Air Systems}

Annual energy usage by compressed-air systems can be estimated using Equation (1) [18].

$A E U=h p \times L \times 0.746 \times h r$

Table 4 Number of audited industrial sector [17]

\begin{tabular}{lc}
\hline \multicolumn{1}{c}{ Sectors } & $\begin{array}{c}\text { Number of audited } \\
\text { factories }\end{array}$ \\
\hline Food products & 9 \\
Wood and wood products & 8 \\
Paper and paper products & 13 \\
Chemicals & 4 \\
Petroleum refineries & 5 \\
Rubber and rubber products & 13 \\
Plastic and plastic products & 7 \\
Glass and glass products & 4 \\
Iron and steel & 5 \\
Fabricated metal products & 12 \\
Cement & 6 \\
\hline Total & $\mathbf{9 1}$ \\
\hline
\end{tabular}

Table 5 Compressed-air energy used in audited industries

\begin{tabular}{ccc}
\hline $\begin{array}{c}\text { Motor Power } \\
(\mathrm{HP})\end{array}$ & Quantity & $\begin{array}{c}\text { Annual energy use } \\
\text { (MWh) }\end{array}$ \\
\hline 0.25 & 754 & 506 \\
0.5 & 432 & 580 \\
0.75 & 543 & 1,094 \\
1 & 893 & 2,398 \\
1.5 & 231 & 931 \\
2 & 432 & 2,320 \\
3 & 671 & 5,406 \\
4 & 5321 & 57,160 \\
5.5 & 112 & 1,654 \\
7.5 & 135 & 2,719 \\
15 & 132 & 5,317 \\
20 & 765 & 41,090 \\
25 & 321 & 21,552 \\
30 & 153 & 12,327 \\
40 & 236 & 25,352 \\
50 & 137 & 18,396 \\
60 & 231 & 37,222 \\
75 & 17 & 3,424 \\
\hline Total energy use (MWh) & $\mathbf{2 3 9 , 4 5 0}$ \\
\hline
\end{tabular}

\subsection{Energy Savings by Using a High-Efficiency Motor}

A high-efficiency motor uses low-loss materials to reduce core, and copper, losses. Reduced losses mean that an energyefficient motor produces a given amount of work with less energy input than that required by a standard motor. Several leading electric-motor manufacturers, mainly in USA and
Europe, have developed product lines of energy-efficient electric motors that are $2-8 \%$ more efficient than the standard motors are [19].

The ratio of the mechanical power supplied by the motor to the electrical power used during operation is the motor's efficiency. High-efficiency motors cost less to operate than do their standard counterparts. Motor efficiencies range from about 70 to over $96 \%$ at full-load rated power [19]. Annual energy savings through replacement of standard efficient motors with highly energy-efficient motors can be estimated by using the methodology described in reference [17]:

$A E S=h p \times L \times 0.746 \times h r \times\left[\frac{1}{E_{s t d}}-\frac{1}{E_{e e}}\right] \times 100$

Annual bill savings associated with the above energy savings can be calculated as:

Savings $=A E S \times c$

Table 6 shows the typical input data needed for electric-motor energy-saving estimation. Table 7 shows the efficiencies of various-capacity motors, against various loads.

Table 6 Input data for motor's energy savings

\begin{tabular}{ll}
\hline Parameters & Value \\
\hline Average usage hours & 6000 \\
Average electricity cost (US\$/kWh) & 0.064 \\
\hline
\end{tabular}

Table 7 Efficiencies of standard, and high-efficiency, motors, against various loads [17]

\begin{tabular}{cccccccc}
\hline HP & Incremental & \multicolumn{2}{c}{ Load (50\%) } & \multicolumn{2}{c}{ Load (75\%) } & \multicolumn{2}{c}{ Load (100\%) } \\
\cline { 3 - 8 } & cost (US\$) & $\mathrm{E}_{\text {std }}$ & $\mathrm{E}_{\text {ee }}$ & $\mathrm{E}_{\text {std }}$ & $\mathrm{E}_{\text {ee }}$ & $\mathrm{E}_{\text {std }}$ & $\mathrm{E}_{\text {ee }}$ \\
\hline 1 & 21 & 70.05 & 75.28 & 74.43 & 79.49 & 77.00 & 80.97 \\
1.5 & 25 & 76.04 & 80.06 & 78.03 & 81.28 & 78.50 & 82.55 \\
2 & 27 & 77.20 & 80.02 & 79.29 & 83.07 & 81.00 & 83.55 \\
3 & 60 & 77.78 & 82.44 & 79.87 & 84.55 & 81.50 & 85.01 \\
4 & 61 & 81.07 & 83.69 & 82.39 & 85.24 & 82.90 & 85.96 \\
5.5 & 68 & 81.15 & 84.35 & 84.73 & 86.50 & 85.30 & 87.75 \\
7.5 & 91 & 84.07 & 85.51 & 86.23 & 87.58 & 86.61 & 89.50 \\
15 & 100 & 84.92 & 88.32 & 86.45 & 89.85 & 87.94 & 90.44 \\
20 & 111 & 86.03 & 88.51 & 87.58 & 91.05 & 88.95 & 91.64 \\
25 & 186 & 87.61 & 90.26 & 88.39 & 91.66 & 89.50 & 91.80 \\
30 & 273 & 88.43 & 90.89 & 89.32 & 91.73 & 90.70 & 91.83 \\
40 & 371 & 88.15 & 90.39 & 90.54 & 91.91 & 90.36 & 92.85 \\
50 & 678 & 89.63 & 91.16 & 89.86 & 92.58 & 92.06 & 93.28 \\
60 & 887 & 87.89 & 90.07 & 91.31 & 92.09 & 91.78 & 93.00 \\
75 & 1172 & 88.77 & 90.86 & 90.19 & 92.72 & 92.44 & 93.02 \\
\hline
\end{tabular}

\subsection{Motor's Energy Savings through Variable Speed Drive}

Most of the systems operate at their full load only for short periods. The most common method is the modulation of speed, of the motors, of pumps, compressors, and fans, to vary their capacity by using VSDs [17]. Variable-frequency drives provide continuous control, matching motor speed to the specific demands of the work being performed. Variablefrequency drives are an excellent choice for adjustable-speed- 
drive users because they allow operators to fine-tune processes while reducing costs of energy and of equipment maintenance. It is very important to select an electric motor of suitable power to work efficiently. In general, big-capacity motors are chosen to meet extra-load demands. Usually, motors operate more efficiently at $75 \%$ or more of rated load. Many ways can be used to estimate the energy savings from use of VSD in industrial motors for various applications [20]. A motor's energy savings through VSD can be estimated as:

$$
E S_{V S D}=n \times P \times H_{\text {avg_usage }} \times S_{S R}
$$

Table 8 shows the potential energy savings from speed reduction, through use of VSD in industrial motors. These data can be been used to estimate a motor's energy savings through use of VSD.

Table 8 Potential savings from VSD [17]

\begin{tabular}{cc}
\hline Average speed reduction (\%) & Potential energy savings (\%) \\
\hline 20 & 44 \\
40 & 73 \\
60 & 89
\end{tabular}

\subsection{Mathematical Formulations of Payback Period}

Payback period is the simplest method of looking at one or more investment projects or ideas. Payback period represents the amount of time that it takes for a capital budgeting project to recover its incremental price. A simple payback period for different energy savings strategies can be calculated using Equation (5).

$$
\text { Payback period }=\frac{\text { Incremental cost }}{\text { Annual dollar savings }}
$$

\subsection{Emissions Mitigation}

The environmental impact of the standard is the potential reduction of greenhouse gasses or other elements that cause negative impact on environment. The common emission pollutants that can be reduced are carbon dioxide, sulfur dioxide, nitrogen oxide and carbon monoxide. The impact can be considered a benefit for the society as well. Potential emissions mitigation by standard can be calculated using the following equation [21]

$E R_{i}^{a}=E S_{i}^{a} \times\left(P E_{i}^{1} \times E m_{p}^{1}+P E_{i}^{2} \times E m_{p}^{2}+\ldots+P E_{i}^{n} \times E m_{p}^{n}\right)$

Table 9 shows emission factors for per-unit energy that can be used to estimate reducible emission.

Table 9 Emission factors of fossil fuels for electricity generation [21]

\begin{tabular}{lllll}
\hline Fuels & \multicolumn{4}{c}{ Emission factor $(\mathrm{kg} / \mathrm{kWh})$} \\
\cline { 2 - 5 } & $\mathrm{CO}_{2}$ & $\mathrm{SO}_{2}$ & $\mathrm{NO}_{\mathrm{x}}$ & $\mathrm{CO}$ \\
\hline Coal & 1.18 & 0.0139 & 0.0052 & 0.0002 \\
Petroleum & 0.85 & 0.0164 & 0.0025 & 0.0002 \\
Gas & 0.53 & 0.0005 & 0.0009 & 0.0005 \\
Hydro & 0.00 & 0.000 & 0.0000 & 0.0000 \\
others & 0.00 & 0.000 & 0.0000 & 0.0000 \\
\hline
\end{tabular}

\section{Result and Discussion}

\subsection{Energy Savings, Payback Periods and Emission Reductions of Boiler}

Energy use by boiler fan motor for different capacities and percentage of loadings has been estimated and presented in Figure 2. Based on this figure it has been observed that more energy used by boiler fan motors for $60 \%$ loading followed by $40 \%$ as motors are engaged in operation for longer time compared to $80 \%$ and $100 \%$ loadings. It was also found that highest amount of energy used by $15 \mathrm{~kW}$ motor for different percentage of loadings as number of motors are higher than other capacities of motors.

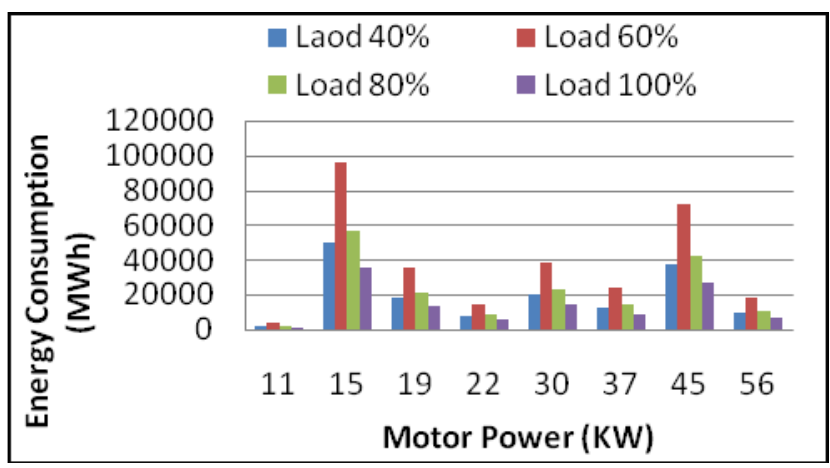

\section{Figure 2 Energy used by different capacity and motor loadings}

Table 9 summarises the cumilative amount of energy and bill that can be saved for different percentage of speed reduction and motor loadings. Payback period for energy savings associated with different percentage of speed reductions has been estimated and presented in Table 11. Emission reduction has been estimated and shown in Table 12. The energy savings and bill savings is shown that it is a protential energy and bill savings option as well as emission reduction. The payback period also economically viable and it is more economical for the high capacity motor.

\subsection{Energy Savings, Payback Periods and Emission Reductions of Air Compressor}

Table 13 presents, for various motor sizes and loads, the energy savings, bill savings, and payback periods resulting from the use of high-efficiency motor. Based on this table and data analysis, $6703 \mathrm{MWh}, 8251 \mathrm{MWh}$, and $10571 \mathrm{MWh}$, total energy, can be saved by using energy-efficient motors, for $50 \%, 75 \%$, and $100 \%$, motor loadings, respectively. Similarly, bill savings for the preceding amounts of energy savings are US $\$ 428,984$, US $\$ 528,042$ and US\$676,538, respectively.

The payback periods when energy-efficient motors were used range from 0.82 to 11.11 years, for various percentages of motor loadings. The periods indicate the cost-effectiveness of energy-efficient motors, as in most cases their payback periods are less than one third of the motor's life (if an average life of 20 years is considered). Installing high efficiency motors in compressor systems reduce annual energy consumption by $2 \%$, with a payback period of less than 3 years [22]. Tables 14 show energy savings, bill savings, and payback periods for various percentages of motor-speed reductions through VSD. Table 14 shows how huge amounts of energy could be saved for various 
percentages of speed reductions. More energy could be saved for higher speed reductions. Along with energy savings, huge amounts could be saved off electricity bill, and associated emission reductions could be achieved through use of VSD in industrial motors in Malaysia. Implementing adjustable speed drives in rotary compressor systems can save $15 \%$ of the annual energy consumption [22]. From Table 14, payback periods for larger motors at higher speed reductions (i.e. speed reduction above $30 \%$ ) are found to be economically viable as the payback periods are short. However, VSD is not cost effective for smaller motors as their payback period is significantly high. Abbott [23] reported that payback periods for VSDs of various motor sizes and categories range from 0.4 years to 1.5 years. From Table 15, it is found that huge amount of emission cab be saved by using variable speed drive. It is also found that more the speed reduction more emission reduction.

\section{Conclusion}

It has been found that maximum amount of energy can be saved for $60 \%$ of motor fan speed reduction for $60 \%$ motor loading using VSD in boiler. However, it was also found that sizeable amount of energy and bill can be saved for $20 \%$ and $40 \%$ speed reduction for different loadings. It was found that payback period for using VSD to save fan motor energy to be 0.23 to 5.58 years. It may be stated that use of VSD in fan motor energy saving is economically very viable for motor capacities $15 \mathrm{~kW}$ and above. Study also found that $69,770,744$ $\mathrm{kg}, 134,558,329 \mathrm{~kg}, 79,738,065 \mathrm{~kg}, 49,836,603 \mathrm{~kg}$ of $\mathrm{CO}_{2}$ emission can be avoided for the associated energy savings as a result of energy savings using VSD for $40 \%, 60 \%, 80 \%$ and $100 \%$ motor loadings. In the compress air sytem, based on data analysis, $6703 \mathrm{MWh}, 8251 \mathrm{MWh}$, and $10571 \mathrm{MWh}$ energy can be saved by using energy-efficient motors, for $50 \%, 75 \%$, and $100 \%$, motor loadings where the bill savings US\$ 428,984, US\$ 528,042 and US\$ 676,538, respectively. It has been found that $52,679 \mathrm{MWh}$ of energy can be saved for $10 \%$ speed reduction using VSDs whereas 213,111 MWh energy can be saved for $60 \%$ speed reduction. So, it can be concluded that more energy could be saved for higher speed reductions. Along with energy savings, huge amounts could be saved off electricity bill, and associated emission reductions could be achieved through use of VSD in industrial motors in Malaysia.

\section{Nomenclature}

$A E U=$ Annual energy consumption $(\mathrm{MWh})$

AES = Annual energy savings $(\mathrm{MWh})$

$\mathrm{c} \quad=$ Average energy cost $(\mathrm{RM} / \mathrm{kWh})$

$C^{a} \quad=$ Capacity of equipment $(\mathrm{kW})$

$E_{e e} \quad=$ Energy efficient motor (\%)

$E M_{i} \quad=$ Total amount of emission (ton)

$E M_{p}{ }^{n} \quad=$ Fossil fuel emission for a unit of electricity generation of fuel type $n$ (ton)

$E P_{i} \quad=$ Electricity production in the year $i(\mathrm{GWh})$

$E_{s r d} \quad=$ Standard efficiency motor (\%)

$E S_{V S D} \quad=$ Energy saving with the application of VSD

$H_{\text {avg_uage }}=$ average usage hour (hr)

$h p \quad=$ Motor rated horsepower (hp)

$h r \quad=$ Annual operating hour $(\mathrm{hr})$

$L \quad=$ Load factor (either $50 \%, 75 \%$ or full load)

$n \quad=$ Number of motor

$P \quad=$ Power factor

$P E_{i}^{n} \quad=$ Percentage of electricity generation in a year $i$ of fuel type $n$ recommended

$S_{S R} \quad=$ Percentage energy savings associated with speed reduction

Table 10 Cumilative energy and bill savings for different percentage of speed reductions and motor loadings

\begin{tabular}{ccccccccc}
\hline \multirow{2}{*}{$\begin{array}{c}\text { Speed } \\
\text { reduction } \\
(\%)\end{array}$} & Load 40\% & Load 60\% & Load 80\% & Load 100\% & Load 40\% & Load 60\% & Load 80\% & Load 100\% \\
\cline { 2 - 9 }$y$ & & & & & & & & \\
\hline 20 & 68,923 & 132,922 & 78,769 & 49,230 & $4,411,052$ & $8,507,028$ & $5,041,202$ & $3,150,751$ \\
40 & 114,349 & 220,530 & 130,685 & $2,123,624$ & $7,318,335$ & $14,113,933$ & $8,363,812$ & $135,911,944$ \\
60 & 139,412 & 268,866 & 159,328 & 99,580 & $8,922,354$ & $17,207,397$ & $10,196,976$ & $6,373,110$ \\
\hline
\end{tabular}


Table 11 Payback period for different percentage of speed reductions using VSDs

\begin{tabular}{|c|c|c|c|c|c|c|c|c|c|c|c|c|}
\hline \multirow{2}{*}{$\begin{array}{l}\text { Motor } \\
\text { power } \\
(\mathrm{kW})\end{array}$} & \multicolumn{4}{|c|}{ For $20 \%$ speed reduction } & \multicolumn{4}{|c|}{ For $40 \%$ speed reduction } & \multicolumn{4}{|c|}{ For $60 \%$ speed reduction } \\
\hline & $\begin{array}{l}\text { Load } \\
40 \%\end{array}$ & $\begin{array}{l}\text { Load } \\
60 \%\end{array}$ & $\begin{array}{l}\text { Load } \\
80 \%\end{array}$ & $\begin{array}{l}\text { Load } \\
100 \%\end{array}$ & $\begin{array}{l}\text { Load } \\
40 \%\end{array}$ & $\begin{array}{l}\text { Load } \\
60 \%\end{array}$ & $\begin{array}{l}\text { Load } \\
80 \%\end{array}$ & $\begin{array}{l}\text { Load } \\
100 \%\end{array}$ & $\begin{array}{l}\text { Load } \\
40 \%\end{array}$ & $\begin{array}{l}\text { Load } \\
60 \%\end{array}$ & $\begin{array}{l}\text { Load } \\
80 \%\end{array}$ & $\begin{array}{l}\text { Load } \\
100 \%\end{array}$ \\
\hline 11 & 3.98 & 2.07 & 3.49 & 5.58 & 2.40 & 1.25 & 2.10 & 0.13 & 1.97 & 1.02 & 1.72 & 2.76 \\
\hline 15 & 0.25 & 0.13 & 0.22 & 0.35 & 0.15 & 0.08 & 0.13 & 0.01 & 0.12 & 0.06 & 0.11 & 0.17 \\
\hline 19 & 0.24 & 0.13 & 0.21 & 0.34 & 0.15 & 0.08 & 0.13 & 0.01 & 0.12 & 0.06 & 0.11 & 0.17 \\
\hline 22 & 0.49 & 0.25 & 0.43 & 0.68 & 0.29 & 0.15 & 0.26 & 0.02 & 0.24 & 0.13 & 0.21 & 0.34 \\
\hline 30 & 0.26 & 0.14 & 0.23 & 0.37 & 0.16 & 0.08 & 0.14 & 0.01 & 0.13 & 0.07 & 0.11 & 0.18 \\
\hline 37 & 0.27 & 0.14 & 0.23 & 0.37 & 0.16 & 0.08 & 0.14 & 0.01 & 0.13 & 0.07 & 0.12 & 0.18 \\
\hline 45 & 0.06 & 0.03 & 0.05 & 0.08 & 0.03 & 0.02 & 0.03 & 0.00 & 0.03 & 0.01 & 0.02 & 0.04 \\
\hline 52 & 0.16 & 0.09 & 0.14 & 0.23 & 0.10 & 0.05 & 0.09 & 0.01 & 0.08 & 0.04 & 0.07 & 0.11 \\
\hline
\end{tabular}

Table 12 Emission reduction (tons) for $\mathbf{4 0 \%}$ speed reduction

\begin{tabular}{ccccccccccc}
\hline HP & Incre- & \multicolumn{3}{c}{ Energy savings (MWh) } & \multicolumn{2}{c}{ Bill savings (US\$/year) } & \multicolumn{3}{c}{ Payback period (year) } \\
\cline { 3 - 11 } & mental & Load & Load & Load & Load 50 & Load & Load & Load & Load & Load \\
& Price & $50 \%$ & $75 \%$ & $100 \%$ & $\%$ & $75 \%$ & $100 \%$ & $50 \%$ & $75 \%$ & $100 \%$ \\
\hline 1 & 21 & 198 & 256 & 255 & 12,686 & 16,408 & 16,290 & 1.51 & 1.17 & 1.18 \\
1.5 & 25 & 51 & 60 & 97 & 3,277 & 3,815 & 6,204 & 1.74 & 1.49 & 0.92 \\
2 & 27 & 88 & 166 & 146 & 5,649 & 10,653 & 9,326 & 2.04 & 1.08 & 1.24 \\
3 & 60 & 327 & 468 & 456 & 20,953 & 29,971 & 29,213 & 1.92 & 1.34 & 1.37 \\
4 & 61 & 1,840 & 2,899 & 4,091 & 117,735 & 185,565 & 261,809 & 2.77 & 1.76 & 1.25 \\
5.5 & 68 & 59 & 45 & 76 & 3,750 & 2,906 & 4,854 & 2.03 & 2.62 & 1.57 \\
7.5 & 91 & 45 & 61 & 123 & 2,905 & 3,890 & 7,854 & 4.24 & 3.16 & 1.57 \\
15 & 100 & 149 & 141 & 145 & 9,554 & 9,041 & 9,260 & 1.38 & 1.45 & 1.42 \\
20 & 111 & 1,164 & 1,111 & 1,614 & 74,504 & 71,126 & 103,316 & 1.14 & 1.19 & 0.82 \\
25 & 186 & 468 & 712 & 948 & 29,950 & 45,587 & 60,690 & 1.99 & 1.31 & 0.98 \\
30 & 273 & 59 & 221 & 279 & 3,761 & 14,132 & 17,843 & 11.11 & 2.96 & 2.34 \\
40 & 371 & 594 & 787 & 1,254 & 38,008 & 50,339 & 80,261 & 2.30 & 1.74 & 1.09 \\
50 & 678 & 596 & 566 & 310 & 38,132 & 36,226 & 19,868 & 2.44 & 2.56 & 4.68 \\
60 & 887 & 928 & 626 & 676 & 59,424 & 40,051 & 43,277 & 3.45 & 5.12 & 4.73 \\
75 & 1172 & 136 & 130 & 101 & 8,699 & 8,332 & 6,471 & 2.29 & 2.39 & 3.08 \\
\hline
\end{tabular}

Table 13 Energy savings and payback periods for high-efficiency motor

\begin{tabular}{cccccccccccccccccc}
\hline HP & \multicolumn{3}{c}{ For 40\% Load } & \multicolumn{4}{c}{ For 60\% Load } & \multicolumn{3}{c}{ For 80\% Load } & \multicolumn{3}{c}{ For 100\% Load } \\
\cline { 2 - 14 } & $\mathrm{CO}_{2}$ & $\mathrm{SO}_{2}$ & $\mathrm{NO}_{\mathrm{x}}$ & $\mathrm{CO}$ & $\mathrm{CO}_{2}$ & $\mathrm{SO}_{2}$ & $\mathrm{NO}_{\mathrm{x}}$ & $\mathrm{CO}$ & $\mathrm{CO}_{2}$ & $\mathrm{SO}_{2}$ & $\mathrm{NO}_{\mathrm{x}}$ & $\mathrm{CO}$ & $\mathrm{CO}_{2}$ & $\mathrm{SO}_{2}$ & $\mathrm{NO}_{\mathrm{x}}$ & $\mathrm{CO}^{2}$ \\
\hline 11 & 680 & 4 & 2 & 0 & 1311 & 8 & 4 & 1 & 777 & 5 & 2 & 0 & 12627 & 76 & 36 & 8 \\
15 & 18,165 & 109 & 51 & 11 & 35,032 & 210 & 99 & 21 & 20,760 & 124 & 59 & 13 & 33,7347 & 2019 & 951 & 205 \\
19 & 6813 & 41 & 19 & 4 & 13,140 & 79 & 37 & 8 & 7786 & 47 & 22 & 5 & 12,6531 & 757 & 357 & 77 \\
22 & 2728 & 16 & 8 & 2 & 5261 & 31 & 15 & 3 & 3118 & 19 & 9 & 2 & 50,663 & 303 & 143 & 31 \\
30 & 7264 & 43 & 20 & 4 & 14,009 & 84 & 40 & 9 & 8301 & 50 & 23 & 5 & 134,898 & 808 & 380 & 82 \\
37 & 4547 & 27 & 13 & 3 & 8769 & 52 & 25 & 5 & 5196 & 31 & 15 & 3 & 84,439 & 505 & 238 & 51 \\
45 & 13,632 & 82 & 38 & 8 & 26,290 & 157 & 74 & 16 & 15,579 & 93 & 44 & 9 & 253,163 & 1515 & 714 & 154 \\
52 & 3400 & 20 & 10 & 2 & 6557 & 39 & 18 & 4 & 3886 & 23 & 11 & 2 & 63,138 & 378 & 178 & 38 \\
\hline
\end{tabular}


Table 14 Motor's energy savings through VSD, for various speed-reduction percentages

\begin{tabular}{cccccccccc}
\hline HP & \multicolumn{2}{c}{ Energy savings (MWh/year) } & \multicolumn{2}{c}{ Bill savings } & (USD/year) & \multicolumn{3}{c}{ Payback period (year) } \\
\cline { 2 - 9 } & $20 \%$ & $40 \%$ & $60 \%$ & $20 \%$ & $40 \%$ & $60 \%$ & $20 \%$ & $40 \%$ & $60 \%$ \\
\hline 1 & 1,055 & 1,751 & 2,134 & 67,534 & 112,046 & 136,604 & 56.0 & 33.7 & 27.7 \\
1.5 & 409 & 679 & 828 & 26,205 & 43,476 & 53,005 & 39.0 & 23.5 & 19.3 \\
2 & 1,021 & 1,694 & 2,065 & 65,341 & 108,407 & 132,168 & 30.6 & 18.4 & 15.1 \\
3 & 2,379 & 3,946 & 4,811 & 152,236 & 252,574 & 307,932 & 22.0 & 13.3 & 10.9 \\
4 & 25,151 & 41,727 & 50,873 & $1,609,634$ & $2,670,530$ & $3,255,851$ & 17.8 & 10.7 & 8.8 \\
5.5 & 728 & 1,208 & 1,472 & 46,586 & 77,290 & 94,231 & 14.3 & 8.6 & 7.1 \\
7.5 & 1,196 & 1,985 & 2,420 & 76,572 & 127,040 & 154,884 & 11.8 & 7.1 & 5.8 \\
15 & 2,340 & 3,882 & 4,733 & 149,740 & 248,433 & 302,884 & 8.4 & 5.1 & 4.2 \\
20 & 18,079 & 29,995 & 36,570 & $1,157,085$ & $1,919,710$ & $2,340,468$ & 7.6 & 4.6 & 3.7 \\
25 & 9,483 & 15,733 & 19,181 & 606,903 & $1,006,907$ & $1,227,599$ & 7.1 & 4.2 & 3.5 \\
30 & 5,424 & 8,999 & 10,971 & 347,126 & 575,913 & 702,140 & 6.7 & 4.1 & 3.3 \\
40 & 11,155 & 18,507 & 22,563 & 713,914 & $1,184,448$ & $1,444,054$ & 6.3 & 3.8 & 3.1 \\
50 & 8,094 & 13,429 & 16,373 & 518,041 & 859,478 & $1,047,857$ & 6.1 & 3.6 & 3.0 \\
60 & 16,378 & 27,172 & 33,128 & $1,048,183$ & $1,739,031$ & $2,120,189$ & 5.9 & 3.5 & 2.9 \\
75 & 1,507 & 2,500 & 3,047 & 96,424 & 159,976 & 195,039 & 5.7 & 3.5 & 2.8 \\
\hline
\end{tabular}

Table 15 Emission reductions associated with energy savings through VSD

\begin{tabular}{|c|c|c|c|c|c|c|c|c|c|c|c|c|}
\hline \multirow[t]{2}{*}{ HP } & \multicolumn{4}{|c|}{$\begin{array}{l}\text { Emission reductions }(\mathrm{kg}) \text { for } 20 \% \\
\text { speed reduction }\end{array}$} & \multicolumn{4}{|c|}{$\begin{array}{c}\text { Emission reductions }(\mathrm{kg}) \text { for } 40 \% \text { speed } \\
\text { reduction }\end{array}$} & \multicolumn{4}{|c|}{$\begin{array}{l}\text { Emission reductions }(\mathrm{kg}) \text { for } 60 \% \text { speed } \\
\text { reduction }\end{array}$} \\
\hline & $\mathrm{CO}_{2}$ & $\mathrm{SO}_{2}$ & $\mathrm{NO}_{\mathrm{x}}$ & $\mathrm{CO}$ & $\mathrm{CO}_{2}$ & $\mathrm{SO}_{2}$ & $\mathrm{NO}_{\mathrm{x}}$ & $\mathrm{CO}$ & $\mathrm{CO}_{2}$ & $\mathrm{SO}_{2}$ & $\mathrm{NO}_{\mathrm{x}}$ & $\mathrm{CO}$ \\
\hline 1 & 391,366 & 2,343 & 1,104 & 238 & 649,107 & 3,886 & 1,830 & 395 & 649,107 & 3,886 & 1,830 & 395 \\
\hline 1.5 & 48,545 & 291 & 137 & 30 & 81,076 & 485 & 229 & 49 & 81,076 & 485 & 229 & 49 \\
\hline 2 & 325,304 & 1,947 & 917 & 198 & 539,505 & 3,229 & 1,521 & 328 & 539,505 & 3,229 & 1,521 & 328 \\
\hline 3 & 881,324 & 5,276 & 2,485 & 536 & $1,461,867$ & 8,751 & 4,122 & 889 & $1,461,867$ & 8,751 & 4,122 & 889 \\
\hline 4 & $5,345,999$ & 32,001 & 15,076 & 3,252 & $8,869,794$ & 53,095 & 25,013 & 5,395 & $8,869,794$ & 53,095 & 25,013 & 5,395 \\
\hline 5.5 & 178,667 & 1,070 & 504 & 109 & 296,778 & 1,777 & 837 & 181 & 296,778 & 1,777 & 837 & 181 \\
\hline 7.5 & 487,956 & 2,921 & 1,376 & 297 & 809,257 & 4,844 & 2,282 & 492 & 809,257 & 4,844 & 2,282 & 492 \\
\hline 15 & 251,235 & 1,504 & 708 & 153 & 416,890 & 2,496 & 1,176 & 254 & 416,890 & 2,496 & 1,176 & 254 \\
\hline 20 & $6,525,102$ & 39,059 & 18,401 & 3,969 & $10,825,623$ & 64,802 & 30,528 & 6,584 & $10,825,623$ & 64,802 & 30,528 & 6,584 \\
\hline 25 & $2,439,281$ & 14,602 & 6,879 & 1,484 & $4,047,285$ & 24,227 & 11,413 & 2,462 & $4,047,285$ & 24,227 & 11,413 & 2,462 \\
\hline 30 & 975,913 & 5,842 & 2,752 & 594 & $1,619,014$ & 9,691 & 4,566 & 985 & $1,619,014$ & 9,691 & 4,566 & 985 \\
\hline 40 & $2,601,933$ & 15,575 & 7,337 & 1,583 & $4,317,037$ & 25,842 & 12,174 & 2,626 & $4,317,037$ & 25,842 & 12,174 & 2,626 \\
\hline 50 & $1,626,521$ & 9,736 & 4,587 & 989 & $27,063,705$ & 162,003 & 76,320 & 16,461 & $32,995,476$ & 197,511 & 93,047 & 20,069 \\
\hline 60 & $4,908,590$ & 29,383 & 13,842 & 2,986 & $81,142,057$ & 485,716 & 228,821 & 49,353 & $98,926,617$ & 592,174 & 278,973 & 60,170 \\
\hline 75 & $1,256,675$ & 7,522 & 3,544 & 764 & $20,236,456$ & 121,135 & 57,067 & 12,308 & $24,671,844$ & 147,686 & 69,575 & 15,006 \\
\hline
\end{tabular}




\section{References}

[1] Einstein D, Worrell E. Marta Khrushch, Steam Systems in Industry: Energy Use and Energy Efficiency Improvement Potentials, Lawrence Berkeley National Laboratory, Available

http://www.osti.gov/bridge/servlets/purl/789187uTGqsP/native/, 6/09/09

[2] Energy information administration (EIA). International energy annual, online, retrieved $3^{\text {rd }}$ January 2009 from www.eia.doe.gov/iea 2007

[3] ERC, How to save energy and money in boilers and furnace systems, Energy Research Centre (ERC), University of Cape Town, South Africa. 2004

[4] Ozdemir E. Energy conservation opportunities with a variable speed controller in a boiler house", Applied Thermal Engineering 2004; 24: 981-993 http.dx.doi.org/10.1016/j.applthermaleng.2003.11.009

[5] Jayamaha L. Energy efficient building systems: green strategies for operation and maintenance. McGraw Hill Book Company. 2008

[6] Sonia S and Rubin ES. A centurial history of technological change and learning curves for pulverized coal-fired utility boilers. Energy, 2007; 32: 1996-2005. http.dx.doi.org/10.1016/j.energy.2007.03.004

[7] Bayindir R, Sagiroglu S, Colak I. An intelligent power factor corrector for power system using artificial neural networks. Electric Power Systems Research 2009: 52-160

[8] Colak I, Bayindir R, Sefa I. Experimental study on reactive power compensation using a fuzzy logic controlled synchronous motor. Energy Conversion and Management, 2004; 45 (15-16): 2371-2391.

[9] Holdsworth J. Conserving energy in compressed air systems. Plant Engineering, 1997; 51(13):103-104.

[10] Joseph B. Compressed air supply efficiency. A Paper Presented at the IETC, Houston, Southern California Edison, USA, 2004.

[11] Kaya D, Phelan P, Dhau D and Sarac HI. Energy conservation in compressed-air systems. International Journal of Energy Research 2002; 26: pp 837-849 http.dx.doi.org/10.1002/er.823
[12] Mohsen MS and Akash BA. Energy analysis of the steel making industry. International Journal of Energy Research, 1998; 22:1049-1054 http.dx.doi.org/10.1002/(SICI)1099114X(19981010)22:12<1049::AID-ER422>3.0.CO;2-W http.dx.doi.org/10.1002/(SICI)1099114X(19981010)22:12<1049::AID-ER422>3.3.CO;2-N

[13] IPCC Guidelines for National Greenhouse Gas Inventories, volume 3.Greenhouse Gas Inventory Reference Manual. IPCC (Intergovernmental Panel on Climate Change). Revised 1996.

[14] Qureshi TQ and Tassou SA. Variable-speed capacity control in refrigeration systems. Applied Thermal Engineering, 1996; 16(2):103-113 http.dx.doi.org/10.1016/1359-4311(95)00051-E

[15] Kaya D, Yagmur A, Suleyman YK, Kilic FC, Salih EA and Celik C. Energy efficiency in pumps", Energy Conversion and Management, 2008; 49: 1662-1673 http.dx.doi.org/10.1016/j.enconman.2007.11.010

[16] Energy Audit report, Malaysian Energy research centre, 2004.

[17] Saidur R, Rahim NA, Masjuki HH, Mekhilef S, Ping HW, and Jamaluddin MF. End-use energy analysis in the Malaysian industrial sector. Energy, 2009; 34 (2): 153-158. http.dx.doi.org/10.1016/i.energy.2008.11.004

[18] Garcia AGP, Alexandre S, Szklo S, Schaeffer R and McNeil MA. Energy-efficiency standards for electric motors in Brazilian industry, Energy Policy, 2007; 35: 3424-3439. http.dx.doi.org/10.1016/j.enpol.2006.11.024

[19] Akbaba M. Energy conservation by using energy efficient electric motors. Applied Energy, 1999; 64: 149-158

[20] Beggs C. Energy Management and Conservation, Elsevier Ltd. 2002

[21] Mahlia TI. Emissions from electricity generation in Malaysia. Renewable Energy, 2002; 27: 293-30 http.dx.doi.org/10.1016/S0960-1481(01)00177-X

[22] Radgen P. Blaustein. (Eds.): Compressed Air Systems in the European Union. Energy, Emissions, Savings Potential and Policy Actions. LOG_X Verlag. Stuttgart. 2001 (www.isi.fhg.de/publikation/c-air/compressedair.htm).

[23] Abbott LI. Power quality and cost analysis of industrial electrical distribution systems with adjustable speed drives, MS Thesis, California State University, USA, 2006. 